\title{
局所フィードバック制御を用いた分散制御による 音響空間の固有振動の計測
}

\section{Measurement of natural vibration of acoustic space by decentralized control using local feedback control}

\author{
Takashi TANAKA $^{* 1}$, Yutaka KURITA ${ }^{* 2}$, Yasunori OURA ${ }^{* 1}$ and Hiromu NAKAMURA ${ }^{* 3}$ \\ ${ }^{* 1}$ Department of Mechanical Systems Engineering, The University of Shiga Prefecture \\ 2500 Hassaka-cho, Hikone-shi, Shiga 522-8533, Japan \\ ${ }^{*}$ Department of Mechanical Engineering, Osaka Sangyo University \\ 3-1-1 Nakagaito, Daito-shi, Osaka 574-8530, Japan \\ ${ }^{* 3}$ Division of Mechanical Systems Engineering, Graduate School of Engineering, The University of Shiga Prefecture \\ 2500 Hassaka-cho, Hikone-shi, Shiga 522-8533, Japan
}

Received: 15 November 2018; Revised: 11 March 2019; Accepted: 19 May 2019

\begin{abstract}
Natural vibrations of acoustic space expand noise. Measurement of natural vibration is effective to reduce noise based on noise generation mechanism. Acoustic space has many natural vibrations in the noise frequency band. Multi-point excitation is useful for measuring natural vibration, which has mixed modes and high damping. Furthermore, it is necessary to cancel the influence of dumping to excite the modes individually. In this study, the new measurement principle of natural vibrations of acoustic space by multi-point excitation using decentralized control with local feedback control is proposed. An excitation system with local feedback control excites natural vibration without frequency adjustment and cancels damping in acoustic space. Excitation systems with decentralized control can have multi-point excitation without any adjustment of amplitude and phase each other. The proposed acoustic excitation system consists of a speaker, a microphone and a local feedback controller. The controller generates negative damping according to the sound pressure detected by the microphone and feeds it to the speaker. Firstly, it is confirmed that one acoustic excitation system is self-excited at resonance frequency and some resonance peak of the transfer function is sharpened by canceling the effect of damping. Secondly, multi-point excitation using decentralized control using four acoustic excitation systems is performed to excite many modes. All supposed modes are excited without adjustment of the excitation systems according to mode such as amplitude and phase. Finally, it is confirmed that acoustic excitation system has no limitation on the number of installations and has extensibility for higher-order mode excitation.
\end{abstract}

Keywords : Measurement, Natural vibration, Acoustics, Decentralized control, Local feedback control

\section{1. 緒言}

自動車や鉄道車両の室内などの閉空間の快適性向上のために騒音の低減が求められている．走行時の室内にお いて発生する騒音は閉空間を構成する構造振動系と閉空間の音響振動系が連成することで発生することが知られ ている (Qatu et al., 2009). 騒音対策として減衰材や吸音材の付加による各振動系の振動抑制が行われているが, さらなる騒音の低減のためには, 各振動系の振動特性を把握して構造変更を行うなどの対策を行う必要がある.

音響振動系の振動特性を把握する手法として，有限要素解析などの数值解析手法（林他，1994） と実際に音響 空間を音響加振する実験モード解析手法（清野他，2004）（Peeters et al., 2014）がある．近年は数值解析手法の発

\footnotetext{
No.18-00449 [DOI:10.1299/transjsme.18-00449], J-STAGE Advance Publication date : 27 May, 2019

本論文は，Dynamics and Design Conference 2018 講演論文集(2018), No.325の掲載内容に基づいた論文である.

*1 正員, 滋賀県立大学 (厂522-8533 滋賀県彦根市八坂町 2500)

$*_{2}$ 正員, フェロー, 大阪産業大学（干574-8530 大阪府大東市中垣内 3-1-1）

*3 学生員, 滋賀県立大学大学院 工学研究科

E-mail of corresponding author: tanaka.ta@mech.usp.ac.jp
} 
展によって, 試作品を作成する前に数值解析による検討を行い, 設計の問題点を改善している（古屋他, 2014）. さらに，解析結果を検証するために，実機を加振する実験モード解析が行われている（Yoshimura et al., 2012）.

車室空間は固有振動の計測が困難な音響空間である. 空気中を伝わる音の速度は周波数によらず一定であるた め, 音響空間は一次遅れ特性を有する. そのため, 1 点加振で音響振動特性を計測した場合, 加振点からの距離 に応じて振動が遅れてしまい，固有振動数で定在波が形成できない．また，3 次元音響空間では固有振動が狭い 周波数範囲に密集するので，個々の固有振動を個別に計測することが困難である．さらに，吸音材の付加によっ て大減衰系となっているため, 振動が空間全体に伝わりきらない.このような音響空間の振動特性を計測するた めには多点加振が必要である.

多点加振の手法として, 励起したい固有振動に合わせて加振機ごとに周波数, 振幅, 加振機間の位相の調整を 行う（集中制御）加振法が用いられている. 複数の加振機を用いることで振動を全体にいきわたらせ，固有振動 モードに合わせて振幅と加振機間の位相を管理することで定在波を形成する. 多点加振を用いることで大減衰を 有する系の固有振動を計測することができる，一方で，固有振動モードのシミュレーションによる事前把握が必 要であることや，加振機の数に比例して調整パラメータが膨大になるという問題がある.

著者らは機械振動系の振動特性を利用した局所フィードバック制御による自励駆動法と，自励振動子の相互同 期現象を利用したアクチュエータごとの調整を必要としない分散制御による多点加振法を開発した（栗田他, 2010). 加振点と計測点が同じ位置に配置（共配置）されたときの伝達関数において，固有振動数で位相が $90^{\circ}$ 遅れる，そこで，位相をさらに $90^{\circ}$ 遅らせるフィードバック制御コントローラを用いると，一巡伝達関数におい て固有振動数で $180^{\circ}$ 遅れになる. 同じく, 加振点と計測点が共配置の一巡伝達関数のゲインが 1 を超えると, 固有振動数で自励振動が発生する. そのため, 局所フィードバック制御された加振機は自励振動子となる. 自励 振動子を複数配置することで相互同期し, 各加振機の振幅と加振機間の位相が自動で調整され (分散制御), 固有 振動モードが励起できる.この手法は, 調整パラメータを増やすことなく加振点を増やすことができる.一方で, 狭い周波数帯域に複数の固有振動数が存在する場合に, ゲインが最も高い固有振動のみが発振する. そのため, 近接する固有振動のうちゲインが低い固有振動を励起するには，固有振動モードに合わせてアクチュエータ間の 位相を固定する手法 (クロスフィードバック制御) が提案されている.このような分散制御を用いた多点加振は, 音響系の未知の固有振動モードの計測に応用できるのではないかと考えた。

本研究では, アクチュエータ間の位相制御を必要としない分散制御による多点加振を提案し, 音響空間の固有 振動計測技術を開発する．固有振動が密集し減衰の大きい音響空間では，固有振動を個別に計測することが困難 である．そこで，提案手法では，加振機位置の減衰力と釣り合うように制御力を発生させる．このとき，外部か ら入力した加振指令信号と計測信号の伝達関数は，減衰の影響を取り除いた振動特性になると考えられる. 減衰 の影響を取り除いた共配置の伝達関数では, 重解でない限り固有振動数間で必ず反共振が存在する. さらに, 位 相が固有振動数の前後で $180^{\circ}$ 遅れ, 反共振周波数で $180^{\circ}$ 回復する特性となる. よって, 固有振動の密集と減 衰によって計測困難であった固有振動を計測することができる.

本論文では, 固有振動計測技術の基礎を確立する. 初めに, 1 点加振では定在波を形成できず, 多点加振が必 要であることを示寸. 次に, 局所フィードバック制御による自励駆動と, 局所フィードバック制御された多数の 加振機を用いた分散制御の原理を説明し, 音響加振系への適用法について述べる. 分散制御による多点加振を行 い，集中制御と同様の加振ができていることを確認する.さらに，伝達関数においてゲインのピーク周波数で位 相が $90^{\circ}$ 遅れになっていることを示す. 最後に, 分散制御による多点加振多点計測で計測した伝達関数から同定 した固有振動モードを示し，1 点加振では計測できなかった固有振動モードが計測できていることを示す.

\section{2. 実験装置}

本章では, 本研究で用いる音響加振ユニットと 3 次元音響空間について説明する. 初めに, 局所フィードバッ ク制御による音響加振を実現する音響加振ユニットの構成を述べる. 次に, 計測対象として作成した 3 次元音響 空間を示し，音響加振ユニットとモード形状の計測用マイクロホンの配置について説明する．最後に，1 点加振 および集中制御による多点加振で計測した振動特性を示し, 多点加振の必要性を確認する. 


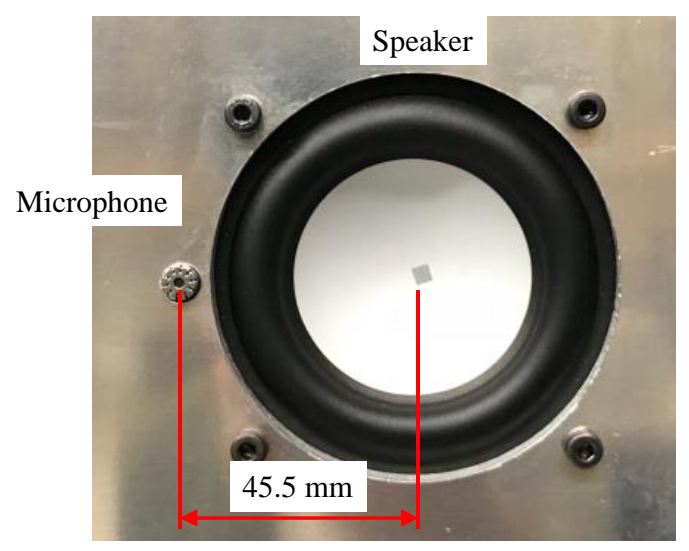

Fig. 1 Acoustic excitation unit. This unit consists of speaker and microphone. The distance between speaker and microphone is $45.5 \mathrm{~mm}$.
Table 1 Speaker specifications.

\begin{tabular}{|c|c|}
\hline Nominal diameter & $70 \mathrm{~mm}$ \\
\hline Nominal impedance & $8 \Omega$ \\
\hline Resonant frequency & $80 \mathrm{~Hz}$ \\
\hline Sensitivity, $1 \mathrm{~W} / 1 \mathrm{~m}$ & $80 \mathrm{~dB} @ 1 \mathrm{kHz}$ \\
\hline Power capacity, RMS & $20 \mathrm{~W}$ \\
\hline Frequency range $(-10 \mathrm{~dB})$ & $80 \mathrm{~Hz}-15 \mathrm{kHz}$ \\
\hline
\end{tabular}

Table 2 Microphone specifications.

\begin{tabular}{|c|c|}
\hline Sensitivity & $45 \mathrm{mV} / \mathrm{Pa}$ \\
\hline Dynamic range & $122 \mathrm{~dB}$ \\
\hline Frequency range $( \pm 2 \mathrm{~dB})$ & $20 \mathrm{~Hz}-10 \mathrm{kHz}$ \\
\hline Temperature range & $-10{ }^{\circ} \mathrm{C}-50{ }^{\circ} \mathrm{C}$ \\
\hline
\end{tabular}

\section{$2 \cdot 1$ 音響加振ユニット}

本研究では, 加振点位置の音圧を帰還する局所フィードバック制御による音響加振を実現する.そのためには, 共配置になったスピーカーとマイクロホン, 制御部が必要である. 初めに, 本研究で使用したスピーカーとマイ クロホンの配置を図1に示す. スピーカーは小型である8インチのダイナミックスピーカー（AURASOUND社， NS3-193-8A）を用いた。 フィードバックする音圧の計測はコンデンサ型マイクロホン（PCB社，130E20）を使用 した．スピーカー，マイクロホンをできる限り近づけて，45.5 mmの距離に配置した．スピーカーとマイクロン の間に節が存在しないように設置することで共配置とみなした。制御部は，MATLAB/Simulinkで設計し，デジタ ルシグナルプロセッサ(DSP, d-SPACE社, MicroLabBox)を用いて実装した.

\section{$2 \cdot 23$ 次元音響空間}

分散制御を用いた固有振動計測技術の基礎を確立するために，実際の音響空間の固有振動計測の困難性を有し ながら，理論的に固有振動数や固有振動モードを計算可能な直方体形状の閉空間を作成した（図 2). 空間の寸法

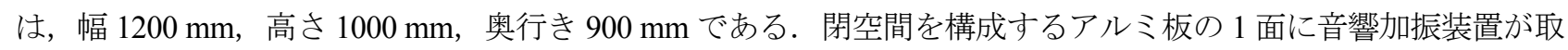
り付けられている. 音圧モードにおいて, 音響空間の全ての固有振動で腹になる位置である四隅に音響加振ユニ ットを配置した. 他の面のうち 3 面に, それぞれ固有振動モード計測用のマイクロホンを取り付けるための穴（7 $\times 8 ， 56 \mathrm{ch} ）$ が空けられている.さらに，音響空間単体の固有振動を計測するために，木材を減衰材として付加 してアルミ板の振動を抑制した.

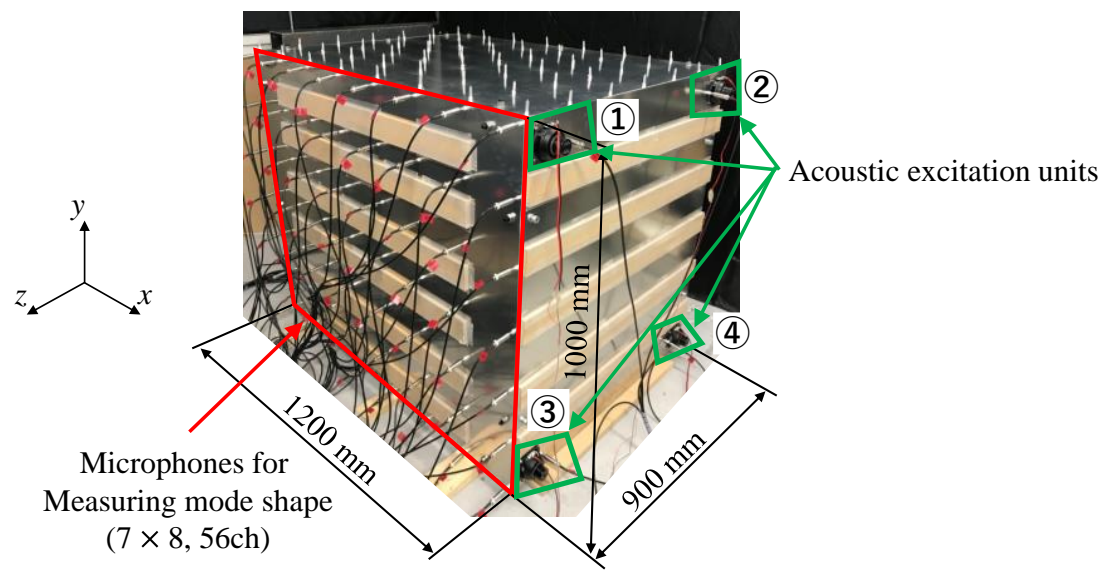

Fig. 2 Three dimensional acoustic space. The size of enclosed space which consists of aluminium plates is $1200 \mathrm{~mm} \times 1000 \mathrm{~mm} \times 900 \mathrm{~mm}$. This enclosed space has 25 theoretical eigenvalues without multiple roots. One side of acoustic space have 4 acoustic excitation systems and three sides of acoustic space have respectively $7 \times 8$ holes for microphones to measure acoustic vibration mode. 
理論的に求めた固有振動数と固有振動モードから，作成した音響空間の特徵を述べる. 直方体の閉空間に生じ る固有振動数 $f_{n}$ の理論值は, 音速を $c$, 直方体内の $x, y, z$ 方向の長さを $L_{x}, L_{y}, L_{z}$, モード次数（節の数）を $n_{x}$, $n_{y}, n_{z}$ とすると，式(1)で表される（大野，山崎，2010）.

$$
f_{n}=\frac{c}{2} \sqrt{\left(\frac{n_{x}}{L_{x}}\right)^{2}+\left(\frac{n_{y}}{L_{y}}\right)^{2}+\left(\frac{n_{z}}{L_{z}}\right)^{2}}
$$

式(1)から得られた固有振動数と固有振動モードを図 3 に示寸. 低次の固有振動では, 固有振動数が十分に離れて おり, 離散的に計測できると思われる. しかし, 高次の固有振動では, 隣接する固有振動数が近接しており, 特 に図 3(j), (k)のように重解ではないがほとんど同じ固有振動数も存在することがわかる.

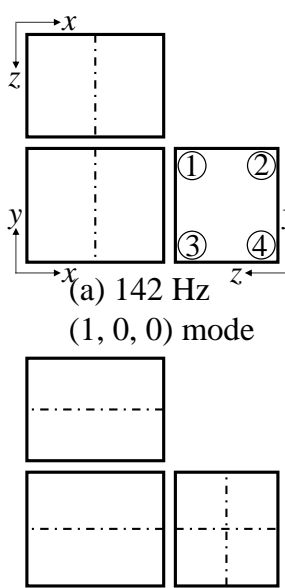

(f) $254 \mathrm{~Hz}$

$(0,1,1)$ mode

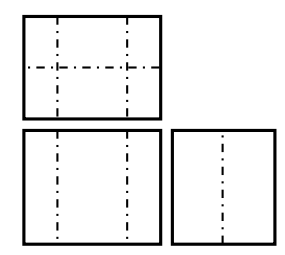

(k) $341 \mathrm{~Hz}$

$(2,0,1)$ mode

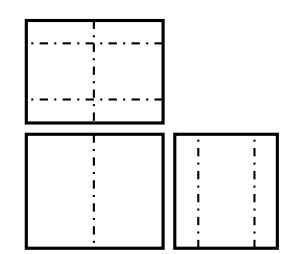

(p) $403 \mathrm{~Hz}$

$(1,0,2)$ mode

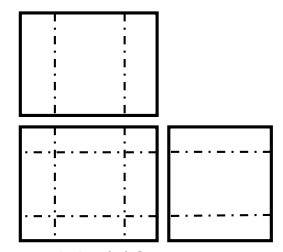

(u) $443 \mathrm{~Hz}$

$(2,2,0)$ mode

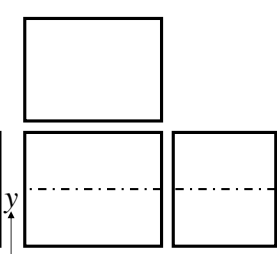

(b) $170 \mathrm{~Hz}$

$(0,1,0)$ mode

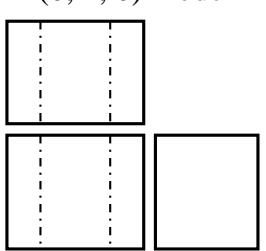

(g) $283 \mathrm{~Hz}$

$(2,0,0)$ mode

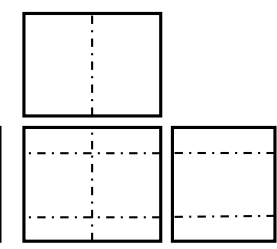

(1) $368 \mathrm{~Hz}$

$(1,2,0)$ mode

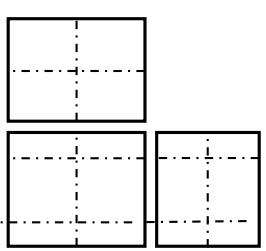

(q) $414 \mathrm{~Hz}$

$(1,2,1)$ mode

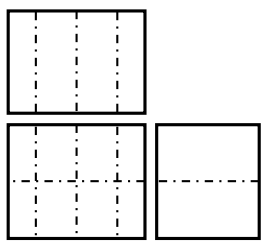

(v) $458 \mathrm{~Hz}$

$(3,1,0)$ mode

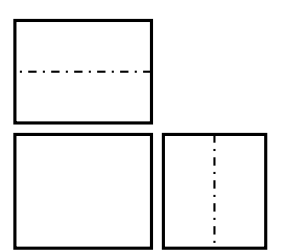

(c) $189 \mathrm{~Hz}$

$(0,0,1)$ mode

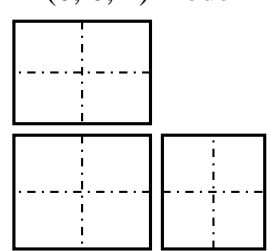

(h) $291 \mathrm{~Hz}$

$(1,1,1)$ mode

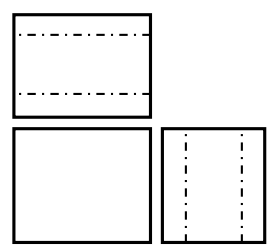

(m) $378 \mathrm{~Hz}$

$(0,0,2)$ mode

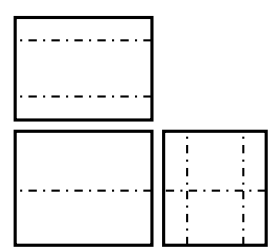

(r) $414 \mathrm{~Hz}$

$(0,1,2)$ mode

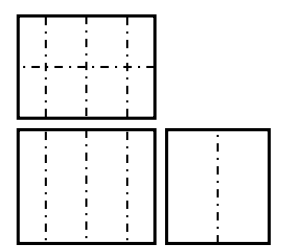

(w) $465 \mathrm{~Hz}$

$(3,0,1)$ mode

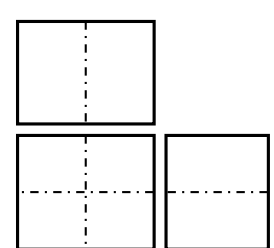

(d) $221 \mathrm{~Hz}$

$(1,1,0)$ mode

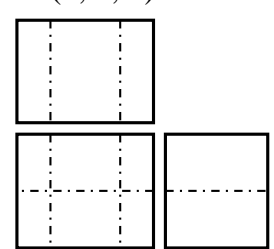

(i) $330 \mathrm{~Hz}$

$(2,1,0)$ mode

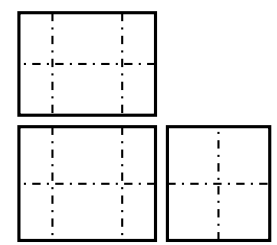

(n) $381 \mathrm{~Hz}$

$(2,1,1)$ mode

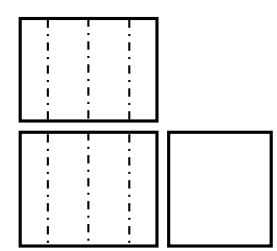

(s) $425 \mathrm{~Hz}$

$(3,0,0)$ mode

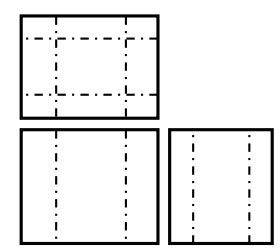

(x) $472 \mathrm{~Hz}$

$(2,0,2)$ mode

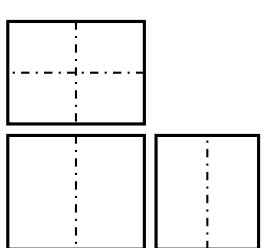

(e) $236 \mathrm{~Hz}$

$(1,0,1)$ mode

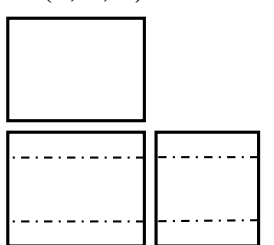

(j) $340 \mathrm{~Hz}$

$(0,2,0)$ mode

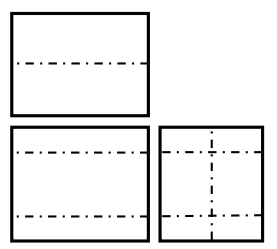

(o) $389 \mathrm{~Hz}$

$(0,2,1)$ mode

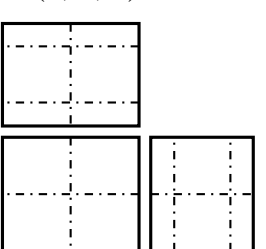

(t) $438 \mathrm{~Hz}$

$(1,1,2)$ mode

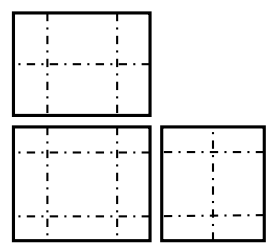

(y) $481 \mathrm{~Hz}$

$(2,2,1)$ mode

Fig. 3 Theoretical natural frequencies and modal diagrams of three-dimensional acoustic space expressing sound pressure (1st mode to 25th mode). Dash lines mean node line. Natural frequencies of lower modal number are crowed in wide bandwidth. Natural frequencies of higher modal number are crowed in narrow bandwidth. So, this acoustic space has not multiple eigenvalue but closely existing eigenvalue in the high frequency bandwidth. 


\section{$2 \cdot 33$ 次元音響空間の伝達特性}

作成した音響空間の固有振動を 1 点加振及び集中制御による多点加振を用いて計測し，多点加振の必要性を示 す. 図 4 に示すような一面の最上段のマイクロホン 8 本で音圧を計測した。加振位置に最も遠いマイクロホンか ら順に Mic 1〜 8 とした. 入力信号の周波数は，後述する分散制御による多点加振実験で実測した（2,2,1）モー ドの固有振動数である $492 \mathrm{~Hz}$ (図 11(y)）とした. $492 \mathrm{~Hz}$ は固有振動数が密集する高周波帯域において最もゲイン が高い固有振動であり，この固有振動を用いて検討を行った. 1 点加振では音響加振ユニット 1 のみに $4 \mathrm{~V}_{0-p}$ の正 弦波を入力した．多点加振では固有振動モードに合わせて位相を調整した $1 \mathrm{~V}_{0-p}$ の正弦波を 4 つ加振機に入力 した．定常状態になったことを確認した後に，計測を開始した.

1 点加振した時の時刻歴波形図 4(a)をみると, 計測位置によって音圧が最大になる時間にずれが生じているこ とがわかる．この原因は，音響振動系は伝播速度が遅いため，1点加振ではスピーカーからの距離に応じて遅れ が発生してしまう（一次遅れ系）ためであると考えた. さらに，固有振動が励起している場合には音響加振ユニ ツトに最も近い Mic 8 と最も遠い Mic 1 で計測した音圧の振幅は一致するはずであるが, 図 4(a)の Mic 1 の音圧は Mic 8 に比べて低下している。このように，1 点加振では音波が空間全体に十分伝播せず，定在波を形成できない ため，作成した音響空間の固有振動を励起できない.

次に，集中制御による多点加振で計測した図 4(b)をみると，すべてのマイクロホンの音圧が最小，最大になる 時間が入力信号とそろっており, Mic 1 と Mic 8 や Mic 2 と Mic 7 などの同じ音圧振幅になるマイクロホン同士の 音圧は近くなっている. よって，多点加振を行うことで，音響振動系の一次遅れ系の影響を取り除き，固有振動 を励起できていることがわかる.

以上の結果より，音響空間の固有振動計測には多点加振が必要であることが示された.

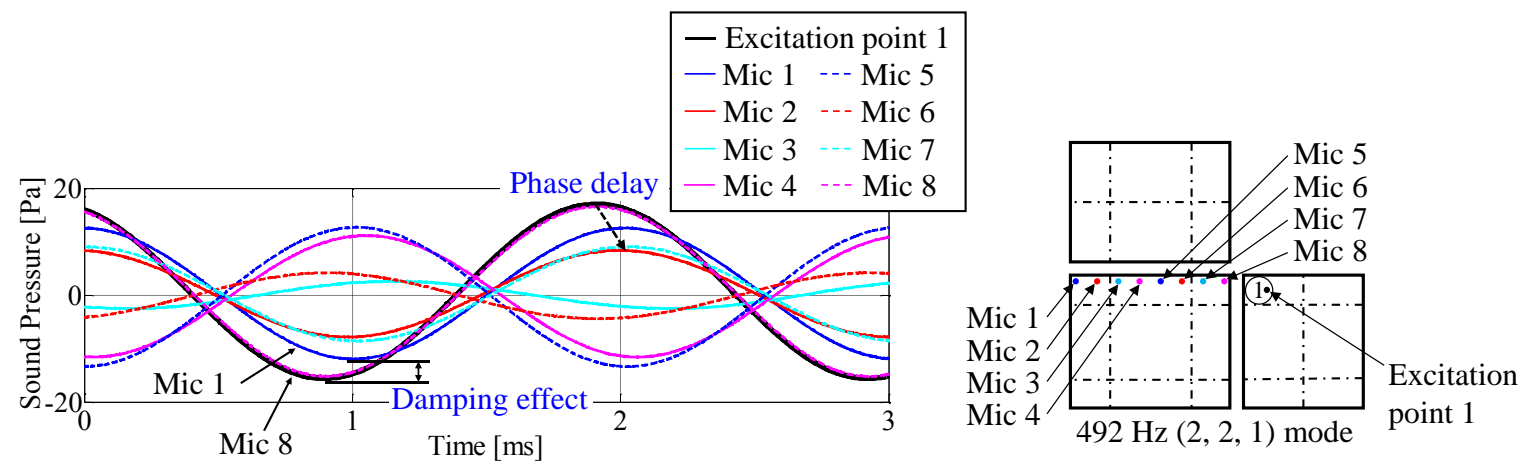

(a) Measurement result of sound pressure using single-point excitation.
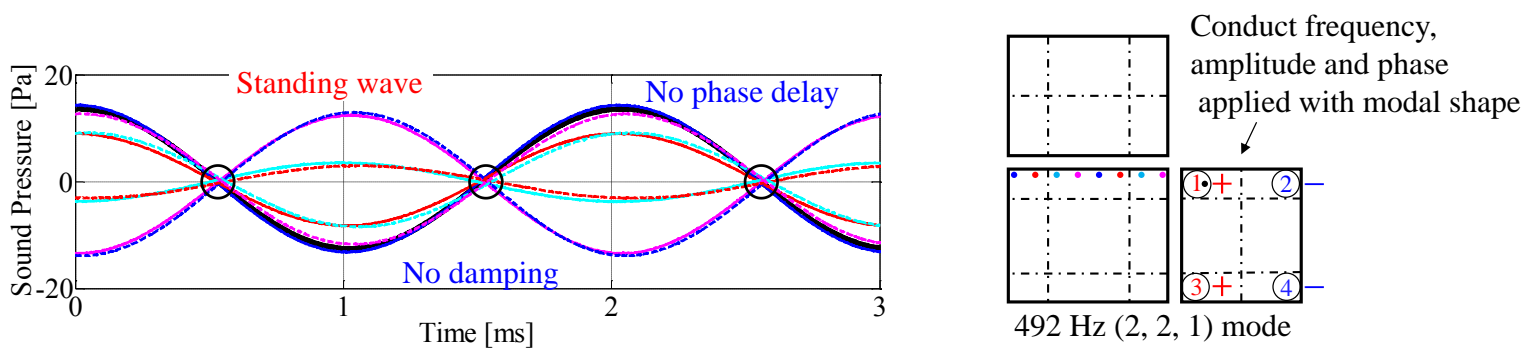

(b) Measurement result of sound pressure using multi-point excitation controlled by centralized control.

Fig. 4 Time history response of three dimensional acoustic space. Fig. 4 (a) is measurement result using single-point excitation. From Fig. 4 (a), amplitude of sound pressure of mic 1 is smaller than amplitude of sound pressure of mic 8 which location is near excitation point 1 because of damping effect. Therefore, phase is delay depending on the distance from excitation point 1 . As result, standing wave is not excited by single-point excitation. Fig. 4 (b) is measurement result using multi-point excitation controlled by centralized control. From Fig. 4 (b), amplitude of sound pressure of mic 1 and mic 8 are the same. Therefore, phase of sound pressure of all microphones are in phase or $180^{\circ}$ delay. As result, standing wave is excited by multi-point excitation. So, multi-point excitation is necessary to excite natural vibration. 


\section{3. 局所フィードバック制御を用いた分散制御による多点加振}

本章では，分散制御による多点加振について説明する．初めに，共配置の加振点から計測点までの伝達関数に おける振動特性を利用した局所フィードバック制御と音響加振への適用について述べる. 次に，局所フィードバ ック制御された加振機を複数配置することで実現する分散制御による多点加振の原理を示す.

局所フィードバック制御は，共配置の計測点の計測データをフィードバックして加振点の加振信号を制御する 手法である (栗田他, 2010). 図 5(a)に示すような多自由度振動系の両側の質点に加える加振力 $u$ から両側の質点 間の相対変位 $h$ までの伝達関数は図 5(b)になる. 図 5(b)のように, 共配置においては共振点と反共振点が交互に 現れ, その加振点で励起しうる全ての固有振動が観測できる. 位相特性を見ると, 共振点の前後で $180^{\circ}$ 遅れ, 反共振点の前後で $180^{\circ}$ 進む. どの程度の周波数範囲で位相が $180^{\circ}$ 変化するかは減衰の大きさに依存して変化 するが，固有振動数で位相が $90^{\circ}$ 遅れ，反共振周波数で位相が $90^{\circ}$ 進む特性は減衰に依存しない.

図 6 に局所フィードバック制御のブロック線図と PI（-D）制御の伝達関数を示す. 固有振動数で位相が $90^{\circ}$ 遅れになる特性に位相を $90^{\circ}$ 遅らせる制御コントローラを設計してフィードバック制御を行うと, 一巡伝達関数 において固有振動数で $180^{\circ}$ 遅れとなる. この時, 固有振動数において一巡伝達関数のゲインが 1 を超えるよう に制御ゲインを設計すると, 固有振動数で自励振動が発生する. 特にゲインが 1 (発振限界) になるとき, 加振 対象物の減衰力と制御力 $F_{C}$ が釣り合う。このときには, 加振指令信号から変位までの振動特性は不減衰振動系と みなせる. 本論文では, 位相を全周波数帯域において $90^{\circ}$ 遅れとする制御 (速度正帰還制御 ( ( - D ) 制御), 積 分負帰還制御 (I 制御)）とゲイン調整を行う制御（比例制御（P 制御) )を組み合わせた PI ( - D ) 制御を用いた. また，積分制御は低周波数帯域でゲインが高くなりドリフトが生じるため，八イパスフィルタにより低周波数の ゲインを低下させた実用積分制御とした，さらに，微分制御は高周波数帯域でゲインが高くなり高周波ノイズを 増幅してしまうため，ローパスフィルタにより高周波数のゲインを低下させた実用微分制御とした.

次に，音響加振への適用方法について述べる．機械振動系を加振する際に用いるアクチュエータは，アクチュ エータ自身の固有振動数よりも低い周波数範囲で使用する. それに対して, 本論文で用いるアクチュエータであ るダイナミックスピーカーは, スピーカーの機械振動系としての固有振動数よりも高い周波数帯域で音を発生さ せるものである. よって, スピーカーの機械振動系としての固有振動数以降で位相が $180^{\circ}$ 遅れる特性を打ち消す ために，図6(a)のように位相反転要素を追加した.

最後に，本論文で用いた分散制御による固有振動励起の原理を説明する．局所フィードバック制御された音響 加振ユニットは, 自励振動子とみな寸ことができる. まず, 図 7 に示すように複数の自励振動子が加振対象物を 介して結合されているとき, 加振対象物の振動モードに応じて各自励振動子の振幅と位相が相互同期しながら発 振する. さらに，各フィードバックコントローラのゲインを発振する限界に設定すると，1 点のスピーカーを用

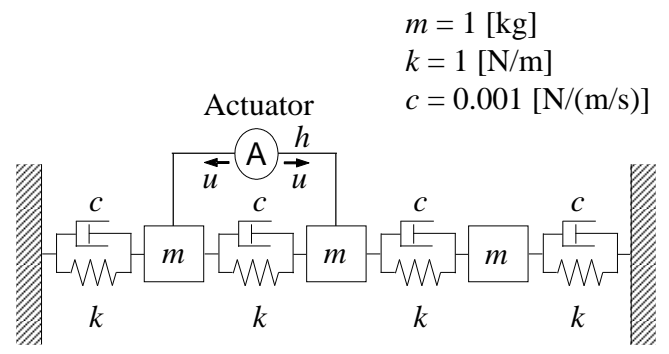

(a) Three degree of freedom system.
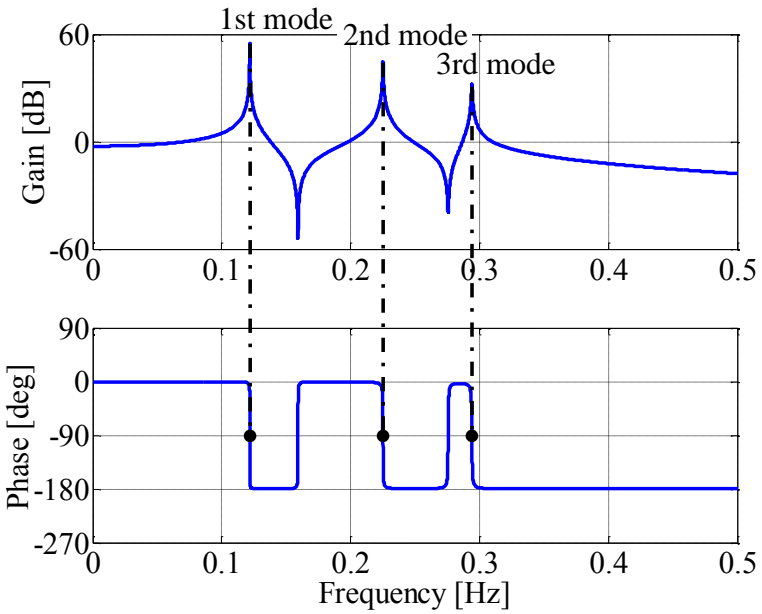

(b) Transfer characteristics.

Fig. 5 Transfer characteristics of three degree of freedom system. Fig. 5 (a) shows sample of three degree of freedom system which has uniform rate of spring $k$ and damping coefficient $c . u$ is amplitude of force exciting by actuator. $h$ is relative displacement. Fig. 5(b) shows transfer characteristics from force $u$ to displacement $h$. The peak of gain and $90^{\circ}$ delay of phase are observed at natural frequency. 


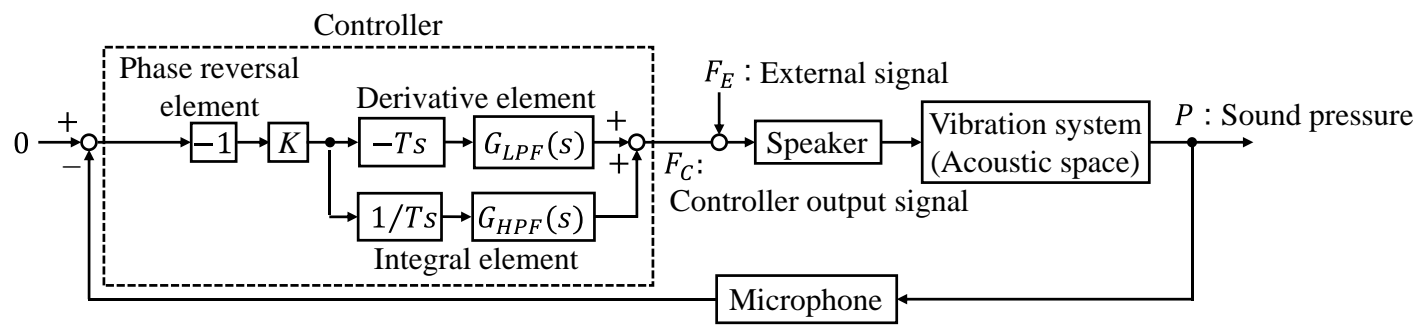

(a) Block diagram of local feedback control.
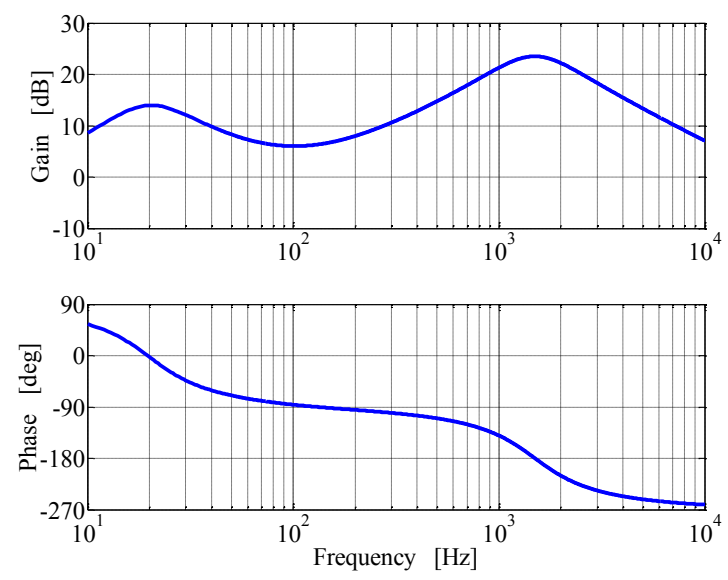

(b) Transfer characteristics of PI(-D) controller.

Fig. 6 Block diagram and transfer characteristics of local feedback control. Fig. 6 (a) shows block diagram of local feedback controller. $P$ is sound pressure. In this research, PI(-D) controller was adopted as $90^{\circ}$ delay controller. Derivative and Integral element have low pass or high pass filter to avoid high gain. Therefore, phase reversal element was adopted to cancel mechanical characteristics of speaker. $F_{C}$ and $F_{E}$ is control signal and external signal. Fig. 6(b) shows transfer characteristics of PI(-D) controller. The phase of the controller is $-90^{\circ}$ in the usage range.

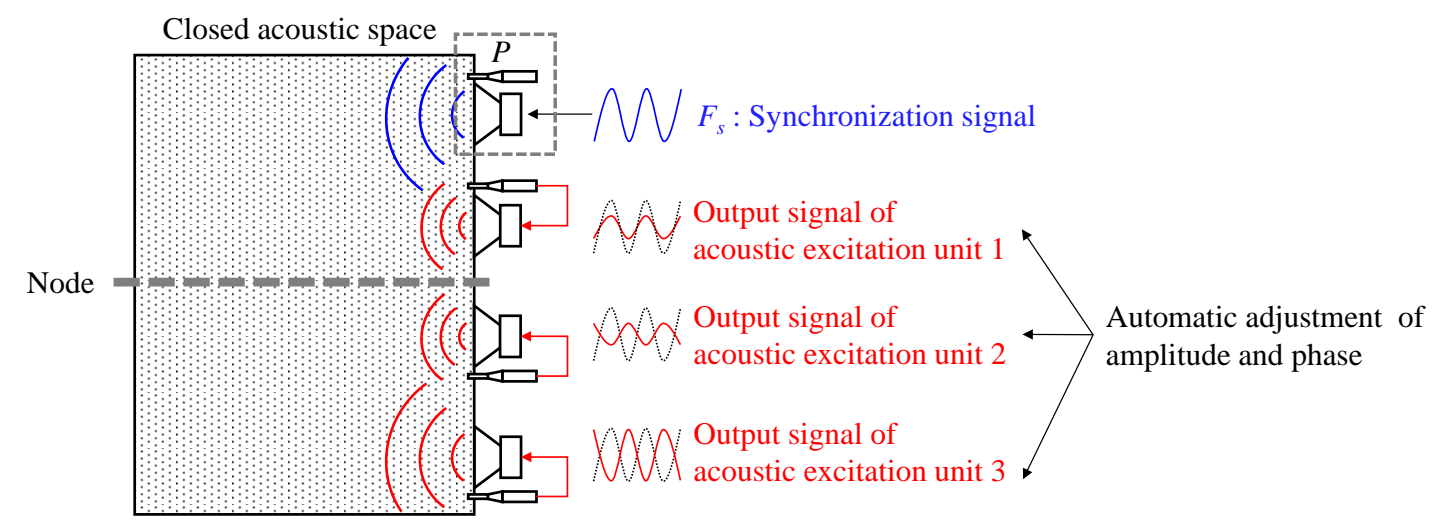

Fig. 7 Excitation mechanism of natural vibration of acoustic space by multi-point excitation using decentralized control. When a speaker is derived by forced synchronization signal $F s$, the amplitude and phase of output signal of acoustic excitation units are adjusted automatically in synchronization with synchronization signal $F s$.

いて強制加振により各音響加振ユニットは自励発振する. このとき, 自励振動子群の発振周波数は強制加振の信 号の周波数に同期する。このとき，各自励振動子は相互同期しているため，音響振動系が有する一次遅れ要素の 影響を取り除くことができる.

\section{4. 分散制御による多点加振を用いた固有振動計測}

本章では，提案する分散制御による多点加振を用いることで，固有振動を容易に計測できることを確認する. 初めに，分散制御による多点加振を行ったときの加振指令から，各音響加振ユニットの加振指令が自動調整され 
ていることを確認する. 次に, 計測した伝達関数からゲインのピーク周波数で位相が $90^{\circ}$ 遅れになっていること を示し, 固有振動計測できていることを確認する.さらに，分散制御による多点加振多点計測により得られた伝 達関数から固有振動モードを同定し，想定される固有振動モードが計測できていることを示す.

\section{$4 \cdot 1$ 分散制御による多点加振}

分散制御によって各音響加振ユニットの加振指令がどのように調整されているかを確認する．同期信号 $F_{S}$ は, 音響加振ユニット 1 のみに多点加振実験で確認した固有振動数である $492 \mathrm{~Hz}, 1 \mathrm{~V}_{0-p}$ の正弦波を入力した. 各音 響加振ユニットの発振ゲインは，最も励起されやすい固有振動が自励発振する発振限界值の $99 \%$ に設定した．定 常状態になったことを確認した後に，計測を開始した.

図 8 (a) に $492 \mathrm{~Hz} ， 1 \mathrm{~V}_{0-p}$ の正弦波を固有振動モードに応じて調整した集中制御の加振指令を，図 8 (b)に分散制 御の加振指令 $F_{S}$ および $F_{C}$ を示す. 図 $8(a)$ に示すように, $492 \mathrm{~Hz}$ の固有振動モードは $(2,2,1)$ モードなので, 音響加振ユニット 1 の加振指令に対して音響加振ユニット 3 の加振指令が同相, 音響加振ユニット 2,4 の加振指 令は逆相になる. 図 8(b) をみると, 音響加振ユニット 1 の同期信号に同期して, 音響加振ユニット 2〜4の加振 指令が自動調整されていることが見て取れる.

この結果より，作製した音響空間の $500 \mathrm{~Hz}$ 以下に存在する固有振動に対して, 開発した音響加振ユニットは共 配置とみなせ，局所フィードバック制御が実現できた。 さらに，自励振動子の相互同期と外力による強制同期を 利用した分散制御により，加振指令の調整が不要な多点加振が実現できた. これにより，提案手法で音響振動系 の一次遅れ系の影響を取り除き，固有振動を励起できると考えられる.
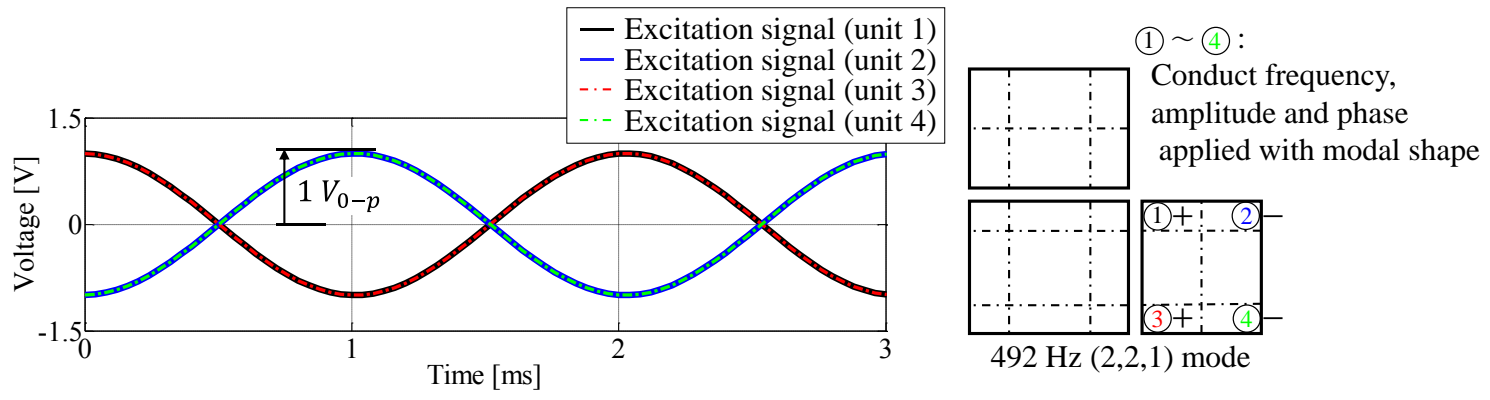

(a) Excitation signal using multi-point excitation controlled by centralized control.

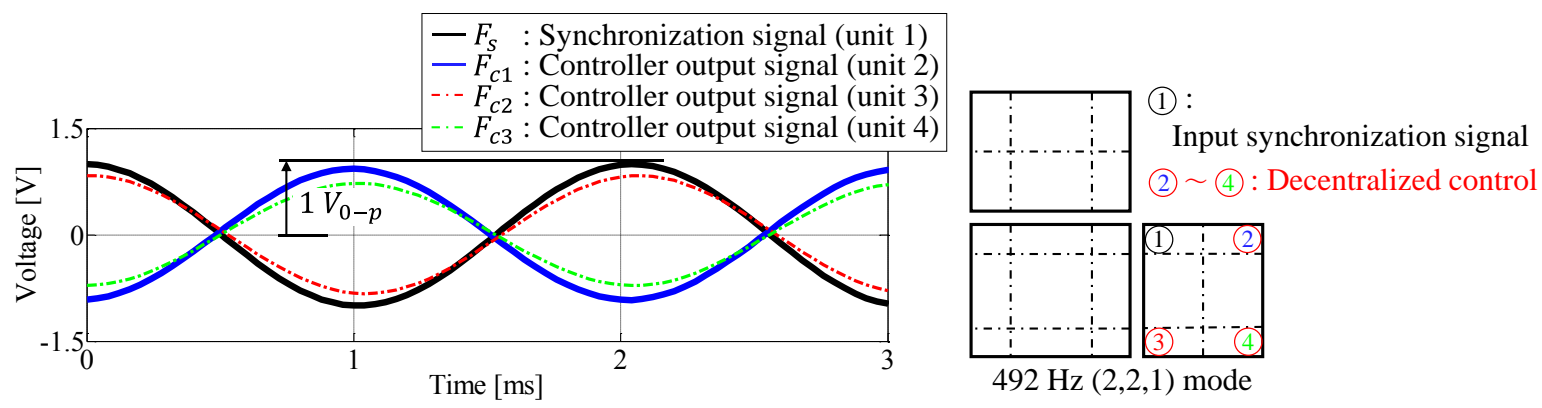

(b) Measurement result of excitation signal formed by multi-point excitation controlled by decentralized control.

Fig. 8 Excitation signal of each acoustic excitation unit. Fig. 8 (a) is excitation signal using multi-point excitation controlled by centralized control. In this technique, four sine waves $\left(492 \mathrm{~Hz}, 1 V_{0-p}\right)$ is adjusted according to natural vibration mode shape. As shown in Fig. 8 (a), excitation signal of acoustic excitation unit 3 is in phase and unit 2 and 4 is inverse phase with unit 1. Fig. 8 (b) is measurement result of multi-point excitation controlled by decentralized control. From Fig. 8 (b), excitation signal of unit 2, 3 and 4 synchronize with synchronization signal of unit 1 and automatically adjusted.

\section{$4 \cdot 2$ 分散制御による多点加振を用いた固有振動計測}

分散制御による多点加振を用いた固有振動計測技術の基礎が確立できていることを，提案手法および 1 点加振 による固有振動計測結果の比較により確認する. 分散制御による多点加振では, 音響加振ユニット 1 のみに $1 \mathrm{~V}_{0-p}$ 
のランダムノイズ信号を同期信号 $F_{S}$ として入力した. 各音響加振ユニットの発振ゲインは，最も励起されやすい 固有振動が自励発振する発振限界值の $99 \%$ に設定した. また， 1 点加振では，音響加振ユニット 1 のみに $4 \mathrm{~V}_{0-p}$ のランダムノイズ信号を入力した.

初めに，計測した伝達関数より，固有振動数の計測結果が改善することを示す１ 1 点加振および分散制御によ る多点加振で計測した伝達関数の比較を図 9 に示す. 図 9(a)に示す伝達関数の全体像より, 分散制御による多点 加振を用いて計測した伝達関数は，1 点加振を用いて計測した伝達関数に比べて固有振動数でゲインの山が高く なるとともに位相の遅れがより急峻になっている.さらに，反共振周波数でゲインの谷が深くなるとともに位相 の回復が顕著になっている. この結果より, 分散制御による多点加振によって減衰の影響を取り除いた伝達関数 を計測できることが示された．これは，分散制御された各音響加振ユニットが減衰力を打ち消すように制御力 $F_{C}$ を発生し，そのF り, 最も効果が大きかった固有振動について考察を行う。1 点加振を用いて計測した伝達関数では, ゲインのピ

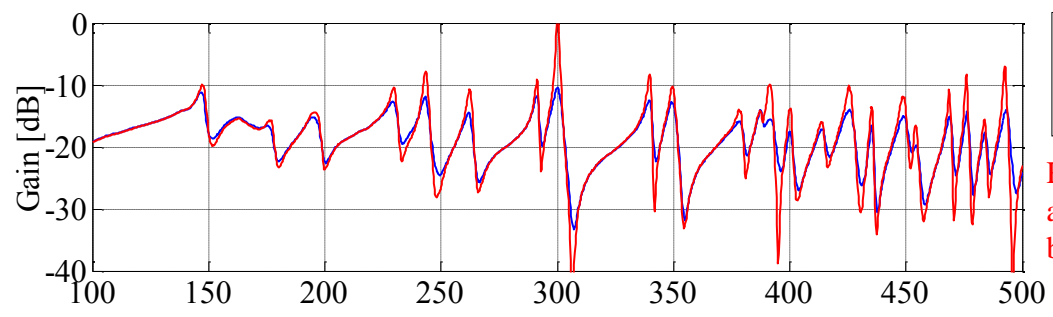

\section{- Single-point excitation \\ - Multi-point excitation using decentralized control}

Resonance peaks and anti-resonance peaks become higher and lower

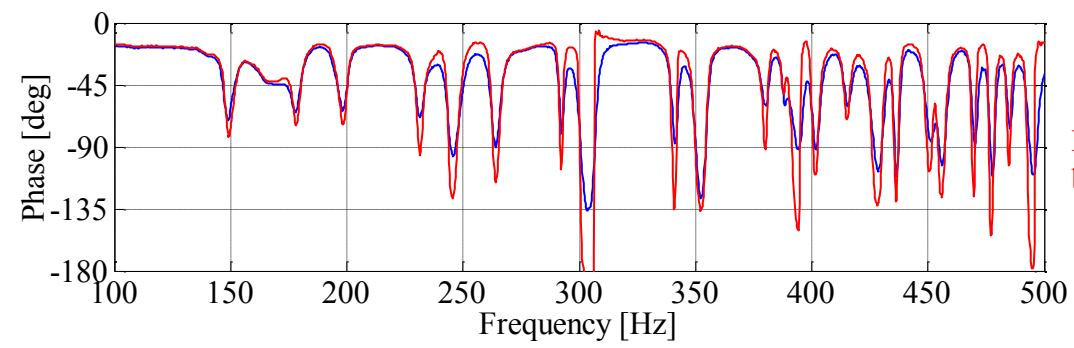

Phase delay and recovery become steeper

(a) Overall image $(100-500 \mathrm{~Hz})$.

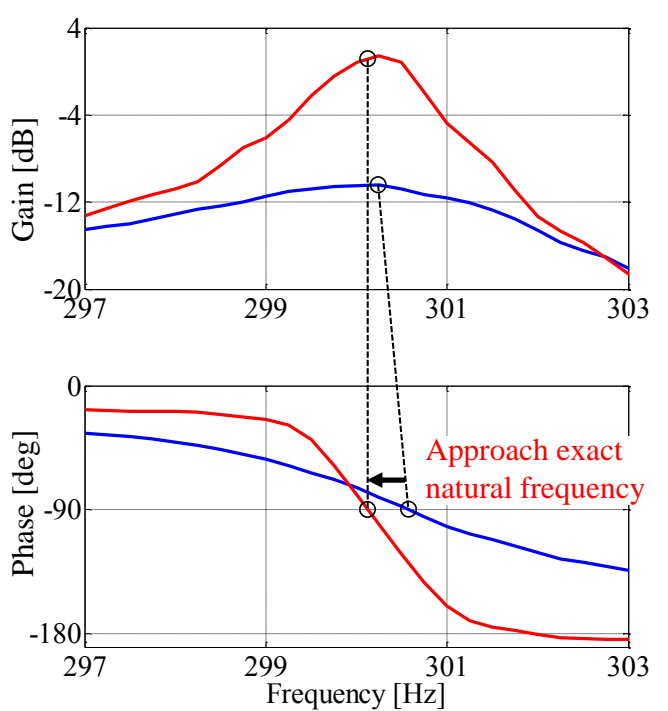

(b) Enlarged view $(297-303 \mathrm{~Hz})$.

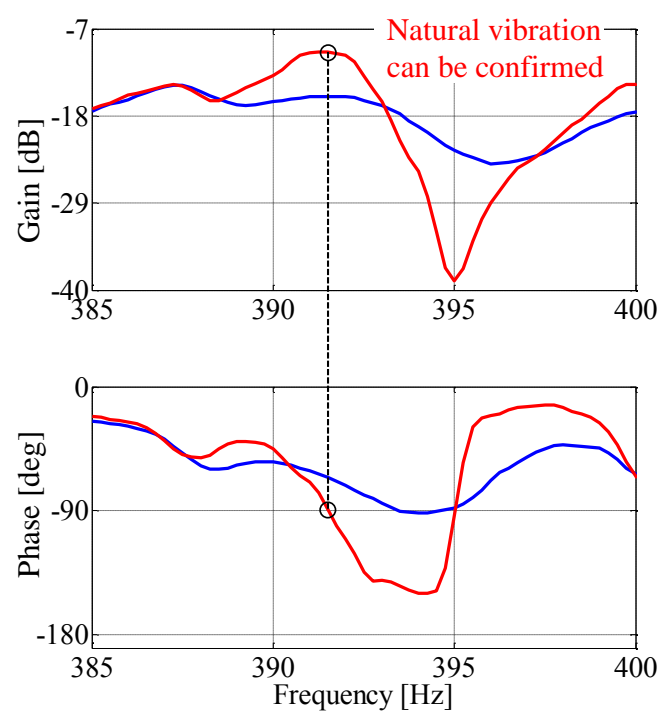

(c) Enlarged view $(385-400 \mathrm{~Hz})$.

Fig. 9 Comparison of transfer characteristics measured by single-point excitation and multi-point excitation controlled by decentralized control. From Fig. 9 (a), gain peak and phase delays at resonance frequencies measured by multi-point excitation controlled by centralized control are higher and steep than single-point excitation. In addition, gain peak and phase recovery at anti-resonance frequencies are lower and obvious. From Fig. 9 (b) and (c), the characteristics that phase is $-90^{\circ}$ at resonance peak can be clearly measured by multi-point excitation controlled by centralized control . 
一ク周波数と位相が $90^{\circ}$ 遅れになる周波数がずれており，固有振動数が明らかでない，それに対して，分散制御 による多点加振を用いて計測した伝達関数では，ゲインのピークが高くなり，位相が固有振動数の前後で 180 遅れている.これは，一巡伝達関数において $300 \mathrm{~Hz}$ の固有振動のゲインが最も高いためであると考えられる.さ らに，ピーク周波数と位相が $90^{\circ}$ 遅れになる周波数が一致し，固有振動数の計測が可能になっている．これは， 分散制御による多点加振によって空間内の音波の位相が揃い, 定在波を形成できているためであると考えられる. 最後に, 図 9(c)の拡大図より, 1 点加振を用いて計測した伝達関数では, ゲインのピーク周波数および位相が $90^{\circ}$ 遅れになる周波数が計測できず，固有振動の存在が確認できない，これは，固有振動の密集や減衰の影響による ものと考えられる. それに対して, 分散制御による多点加振を用いて計測した伝達関数では, ゲインのピーク周 波数で位相が $90^{\circ}$ 遅れになり, 固有振動の存在が確認できた. これは, 図9(b)の固有振動よりも一巡伝達関数に おいてゲインが低い固有振動であるため改善が小さく, 位相が固有振動数の前後で $180^{\circ}$ 遅れにはなっていない. しかし，制御力 $F_{C}$ の効果によって隣接した固有振動の影響が小さくなったため，90遅れが確認できた.

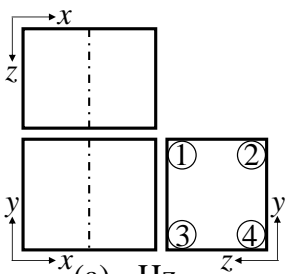

(a) $-\mathrm{Hz}$

$(1,0,0)$ mode

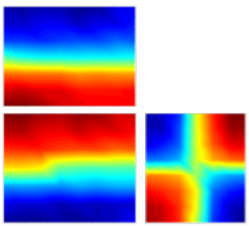

(f) $262 \mathrm{~Hz}$ $(0,1,1)$ mode

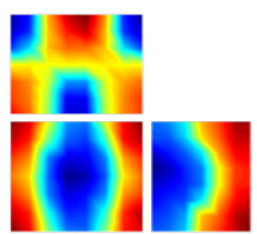

(k) $349 \mathrm{~Hz}$

$(2,0,1)$ mode

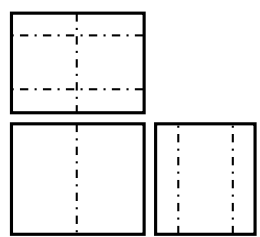

(p) $-\mathrm{Hz}$

$(1,0,2)$ mode

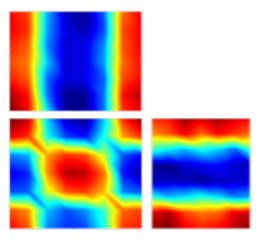

(u) $453 \mathrm{~Hz}$

$(2,2,0)$ mode

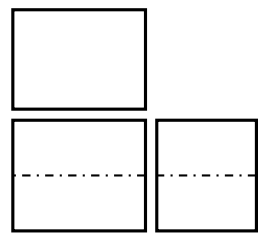

(b) $-\mathrm{Hz}$

$(0,1,0)$ mode

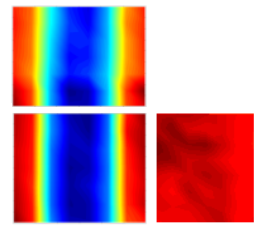

(g) $291 \mathrm{~Hz}$

$(2,0,0)$ mode

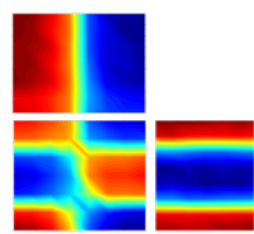

(1) $378 \mathrm{~Hz}$

$(1,2,0)$ mode

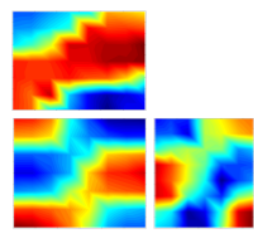

(q) $425 \mathrm{~Hz}$

$(1,2,1)$ mode

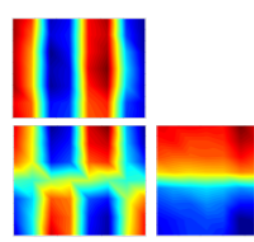

(v) $468 \mathrm{~Hz}$

$(3,1,0)$ mode

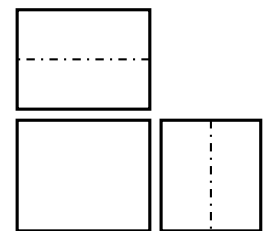

(c) $-\mathrm{Hz}$

$(0,0,1)$ mode

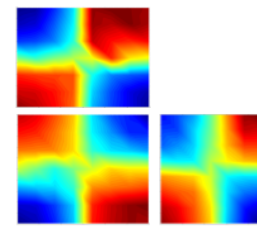

(h) $300 \mathrm{~Hz}$

$(1,1,1)$ mode

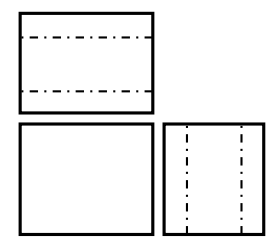

(m) $-\mathrm{Hz}$

$(0,0,2)$ mode

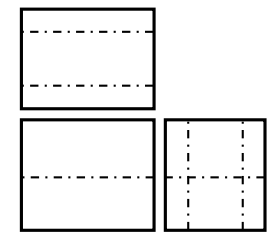

(r) $-\mathrm{Hz}$

$(0,1,2)$ mode

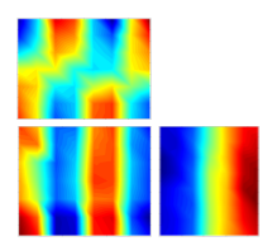

(w) $475 \mathrm{~Hz}$

$(3,0,1)$ mode

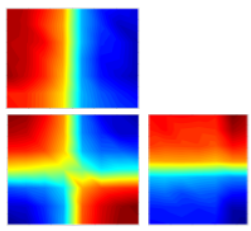

(d) $230 \mathrm{~Hz}$

$(1,1,0)$ mode

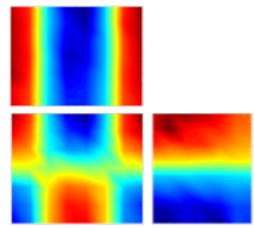

(i) $339 \mathrm{~Hz}$

$(2,1,0)$ mode

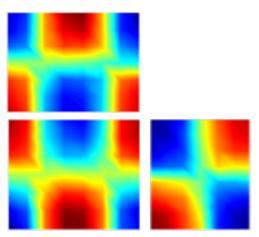

(n) $391 \mathrm{~Hz}$

$(2,1,1)$ mode

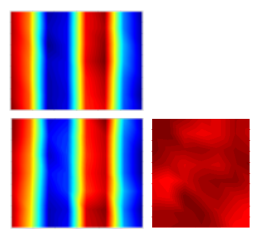

(s) $434 \mathrm{~Hz}$

$(3,0,0)$ mode

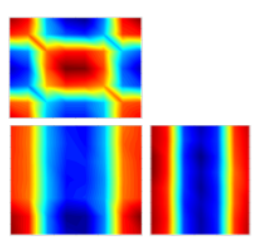

(x) $483 \mathrm{~Hz}$

$(2,0,2)$ mode

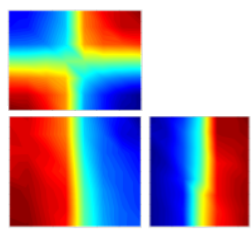

(e) $243 \mathrm{~Hz}$

$(1,0,1)$ mode

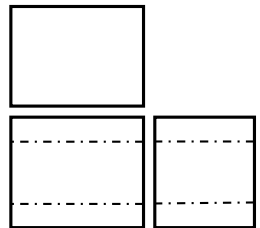

(j) $-\mathrm{Hz}$

$(0,2,0)$ mode

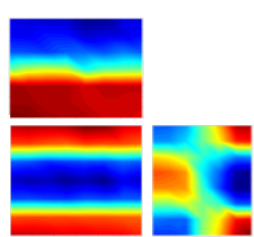

(o) $400 \mathrm{~Hz}$

$(0,2,1)$ mode

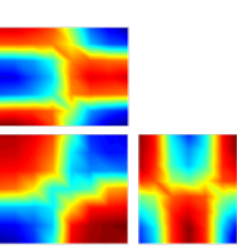

(t) $448 \mathrm{~Hz}$

$(1,1,2)$ mode

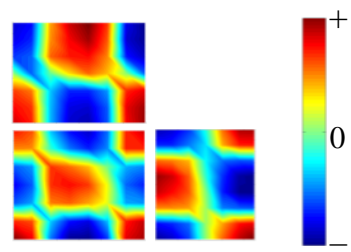

(y) $492 \mathrm{~Hz}$

$(2,2,1)$ mode

Fig. 10 Identification result of natural vibration mode. Using transfer function improved by multi-point excitation controlled by decentralized control, most modes can be identified. The modes of (a), (b), (c), (j), (m), (p), and (r) are modes that can not be identified by decentralized control. 
次に，分散制御による多点加振によって計測した伝達関数において，ゲインのピーク周波数で位相の $90^{\circ}$ 遅れ 計測できた固有振動数に対し，そのモード形状の同定を行った．分散制御による多点加振を行って同期信号 $F_{S}$ から各モード計測用マイクロホンまでの伝達関数を計測し，固有振動モードを同定した結果を図 10 に示す. ただ し, 計測は正面図, 上面図, 左側面図について行ったが，三面図の形で表記するため左側面図の計測結果を右側 面図として表示している．これより，分散制御による多点加振多点計測で計測した伝達関数から，想定される固 有振動モードの大多数を計測できていることが見て取れる. また, 固有振動数の差が $5 \mathrm{~Hz}$ と密集している場合 (図 10(t), (u) ) でも計測できている. 次に, 固有振動数の差が $4 \mathrm{~Hz}$ 以下の密集の場合, 2 つの固有振動をそれぞれ計 測することができなかった. 図 10(j), (m), (r)の固有振動がこれに相当する.これらのモードは, 隣接する図 10(k), (n), (q)の固有振動のゲインが高いために確認できなかった固有振動であると考えられる.この結果は, 本制御手 法では固有振動が隣接する場合（実験では $4 \mathrm{~Hz}$ 以下）, 同期信号の入力点において共配置で計測される伝達関数 のゲインが大きい方のモードに適した加振指令を発生するためである. 一方で, 優先的に励起された図 10(k), (q) の固有振動も，同定されたモード形状は崩れている．これは，隣接した固有振動の影響を受けたためであると考 えられる.このような, 近接する, またはモード形状が複雑である固有振動を計測するには, 音響加振ユニット を増設し, モードの節をまたいで位相差を付けた加振を行う必要があると考えられる。ここで, 提案手法は各加 振機の振幅や位相を調整する必要がないため, 加振点数を容易に拡張できる. そのため, 対象とするモードの次 数に対して十分な加振点数を設けることで計測できるようになると考えられる.

最後に, 分散制御による 4 点加振では, 固有振動の計測結果に対する改善効果が特に小さかった図 10(a), (b), (c)に示寸低周波域の固有振動の計測結果について考察する. これらの固有振動の計測結果に対する改善効果が小 さかったのは，スピーカー特性に原因がある. 今回使用したスピーカーは, $200 \mathrm{~Hz}$ 付近までの周波数帯域では, 本制御手法で必要な位相特性が得られなかった，そのため, 各音響加振ユニットが同期せず, 1 点加振による計 測結果からの改善が小さくなったと考えられる.

以上の結果より，分散制御による多点加振によって空間内の音波の位相が揃い定在波を形成するために，固有 振動数を計測できることが示され，固有振動計測技術の基礎が確立できた.

\section{5. 結 言}

本論文では，音響空間の固有振動を容易に計測する手法の開発を目的として，局所フィードバック制御を用い た分散制御による多点加振を提案した．音響空間の固有振動を計測するためには多点加振が必要であるが，一般 的な多点加振法は数值解析等で予測される固有振動モードを参考にして各加振機の振幅や位相を調整するため実 験に手間や時間を要する. 提案した分散制御による多点加振は, 同期信号に同期して各加振機の振幅や位相が自 動調整されるため, 1 点加振と同等の手間で多点加振を実現できた. 具体的な成果を以下に示す.

（1） 局所フィードバック制御によって自励振動子となる音響加振ユニットを開発し, 固有振動モードを介した 相互同期と同期信号による強制同期を利用した分散制御により,加振指令の調整不要な多点加振技術を開発 した.

（2）分散制御による多点加振によって計測した伝達関数により, 減衰や固有振動の密集のために 1 点加振では 計測できなかった固有振動に対し, ゲインのピーク周波数で位相の $90^{\circ}$ 遅れが計測でき, 固有振動数の計測 結果が改善した. 特に, 一巡伝達関数において最もゲインの高い固有振動数においては, 減衰の影響がほと んどない伝達関数が計測できた.

（3）分散制御による多点加振多点計測で計測した伝達関数から固有振動モードを同定し，1 点加振では計測で きなかった固有振動モードが計測できた.

以上より, 提案手法によって各加振機の振幅や位相を調整せずに, 音響空間の固有振動を容易に計測できるこ とが示された. 今後は, 最適な制御系設計を行うことで, 全ての固有振動の計測結果が十分に改善することが期 待される. また, 加振点数を容易に拡張できるため, 今回計測が不十分であった固有振動に対して音響加振ユニ ットを必要なだけ追加することで計測できるようになると期待される. 


\section{文献}

古屋耕平，松村雄一，多治見大樹，斉藤浩司，相澤伸夫，相互コンプライアンスの構造音響連成系への適用，日本 機械学会論文集, Vol. 80, No. 811 (2014), DOI: 10.1299/transjsme.2014dr0053.

林卓郎，江波戸明彦，吉田祐三，高橋良一，音響モーダル法による構造-音響連成系解析一 MRI の音場解析，日本 機械学会論文集 C 編, Vol. 60, No. 571 (1994), pp. 856-861.

栗田裕，大浦靖典，松田成勝，西出基，分散制御による多自由度振動系の共振点駆動（制御方式の開発と基本性 能の検証)，日本機械学会論文集 C 編, Vol. 76, No. 763 (2010), pp. 557-564.

大野進一, 山崎徹, 機械音響工学, 森北出版 (2010), pp. 102-104.

Peeters, B., El-kafafy, M., Janssens, K. and Lau, J. M. W., Automotive cabin characterization by acoustic modal analysis, Proceedings of The JSAE Annual Congress, Vol. 114-2014543 (2014).

Qatu, M. S., Abdelhamid, M. K., Pang, J. and Sheng, G., Overview of automotive noise and vibration, International Journal of Vehicle Noise and Vibration, Vol. 5, No. 1-2 (2009), pp. 1-35.

清野裕之, 山内裕司, 安田仁彦, 構造・音響連成系の実験解析と理論的考察：付加ばねマス系を有する弾性パネ ルと一端で連成する音響管の場合，日本機械学会論文集 C 編, Vol. 70, No. 691 (2004), pp. 671-678.

Yoshimura, T., Saito, M. and Iba, S., Modal analysis of automotive cabin by multiple acoustic excitation, Proceedings of ISMA2012 - USD2012 (2012), pp. 4051-4060.

\section{References}

Furuya, K., Matsumura, Y., Tajimi, D., Saito, K. and Aizawa, N., Application of mutual mean compliance to vibro-acoustic system, Transactions of the JSME (in Japanese), Vol. 80, No. 811 (2014), DOI: 10.1299/transjsme.2014dr0053.

Hayashi, T., Enamido, A., Yoshida, Y. and Takahashi, R., Structure-acoustic coupled analysis using acoustic modal analysis method: acoustic field analysis on magnetic resonance imaging system, Transactions of the Japan Society of Mechanical Engineers, Series C, Vol. 60, No. 571 (1994), pp. 856-861 (in Japanese).

Kurita, Y., Oura, Y., Matsuda, S. and Nishide, H., Driving at resonance point of multi-degree-of-freedom system by decentralized control: development of control method and verification of basic performance, Transactions of the Japan Society of Mechanical Engineers, Series C, Vol. 76, No. 763 (2010), pp. 557-564 (in Japanese).

Ohno, S. and Yamazaki, T., Vibro-acoustic engineering, Morikita Publishing Co., Ltd. (2010), pp. 102-104 (in Japanese).

Peeters, B., El-kafafy, M., Janssens, K. and Lau, J. M. W., Automotive cabin characterization by acoustic modal analysis, Proceedings of The JSAE Annual Congress, Vol. 114-2014543 (2014).

Qatu, M. S., Abdelhamid, M. K., Pang, J. and Sheng, G., Overview of automotive noise and vibration, International Journal of Vehicle Noise and Vibration, Vol. 5, No. 1-2 (2009), pp. 1-35.

Seino, H., Yamauchi, H. and Yasuda, K., Experimental and theoretical study of a structural-acoustic coupling system: acoustic tube coupled at one end with a flexible panel with a spring-mass system attached, Transactions of the Japan Society of Mechanical Engineers, Series C, Vol. 70, No. 691 (2004), pp. 671-678 (in Japanese).

Yoshimura, T., Saito, M. and Iba, S., Modal analysis of automotive cabin by multiple acoustic excitation, Proceedings of ISMA2012 - USD2012 (2012), pp. 4051-4060. 